\title{
PELATIHAN PENULISAN KARYA TULIS ILMIAH (KTI) BAGI GURU SMA SWASTA DI SIDOARJO
}

\author{
Oleh:

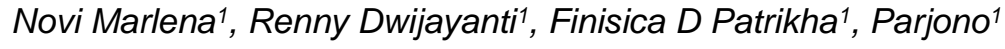 \\ ${ }^{1}$ Fakultas Ekonomi, Universitas Negeri Surabaya \\ 1novimarlena@unesa.ac.id
}

\begin{abstract}
Abstrak
Seorang guru pendamping dalam kegiatan penulisan karya tulis ilmiah harus mampu memahami sistematika dan teknik penulisan karya ilmiah yang baik dan benar. Pelaksanaan pelatihan PKM bertempat di SMA Ulul Albab Taman Sidoarjo. Peserta kegiatan PKM dikuti oleh guru yang berasal dari dua mitra yaitu SMA Ulul Albab Taman Sidoarjo dan SMA Dharma Wamita 4 Sidoarjo sebanyak 25 orang. Kegiatan PKM dilakukan dalam bentuk pelatihan dengan metode bervariasi yaitu ceramah, tanya jawab, diskusi. Dari pelaksanaan kegiatan PKM disimpulkan 1) pelaksanaan pelatihan penulisan karya ilmiah bagi guru SMA di Sidoarjo telah sesuai dengan tahapan yang telah direncanakan sebelumnya, 2) pemahaman guru terhadap teknik penilaian penulisan karya tulis ilmiah siswa diukur dengan menggunakan format penilaian karya tulis ilmiah siswa yang sudah disusun oleh sekolah, 3) secara keseluruhan respon peserta pelatihan Karya Tulis Ilmiah ini merasakan sangat puas terhadap pelatihan yang diberikan. Sedangkan sarannya 1) untuk meningkatkan pemahaman materi pelatihan Karya Tulis IImiah perlu dilakukan pembimbingan secara insentif dan praktik penulisan secara langsung, 2) indikator format penilaian penulisan karya tulis dapat ditambahkan indikator yang lain yaitu kebaruan topik/tema, kedalaman konten materi, penggunaan bahasa yang ilmiah, serta indikator lain yang disesuaikan dengan kebutuhan penulisan karya tulis ilmiah.
\end{abstract}

Kata Kunci: Penulisan Karya Tulis IImiah, Guru, Siswa

\begin{abstract}
A mentor teacher in the activities of writing essay be able to understand the systematic and scientific writing technique is good and right. Implementation training activities held at the PKM in SMA Ulul Albab Taman Sidoarjo. Participants of PKM followed by teachers from the two partners, namely SMA Ulul Albab Taman Sidoarjo and Wamita Dharma SMA 4 Sidoarjo 25 people. PKM activity carried out in the form of training by the method varies the lecture, question and answer, discussion. From the implementation of PKM concluded 1) conducting training of writing essay for high school teachers in Sidoarjo has been in accordance with the stages of pre-planned, 2) understanding of teachers' assessment technique of writing essay students were measured using the format ratings essay of students who have been compiled by school, 3) the overall response of the trainee's essay feel very satisfied with the training provided. While suggesting 1) to improve the understanding of training materials essay needs to be done coaching in incentives and the practice of writing directly, 2) indicator assessment format of writing essay can be added other indicators that the novelty of the topic/theme, the depth of the content material, the use of the language of scientific, as well as other indicators that are to the needs of writing essay.
\end{abstract}

Keywords: Essay Writing, Teacher, Student

\section{PENDAHULUAN}

Kemampuan menulis harus dimiliki oleh setiap orang yang bergerak di dunia pendidikan. Menulis merupakan kegiatan komunikasi berupa penyampaian ide, gagasan, perasaan, kehendak, pesan secara tertulis kepada pihak lain. Penulisan karya ilmiah adalah sebuah karya tulis yang penyusunannya didasarkan pada kajian ilmiah dengan landasan ilmu pengetahuan tertentu. Pemaparan karya ilmiah harus sistematis, logis dan cermat dalam segala aspek termasuk juga aspek bahasa. Kriteria karya ilmiah harus bersifat objektif, rasional dan tidak emosional berdasarkan fakta dan tersusun secara sistematik dan runtut (Maryadi, 2002).

Tidak hanya guru saja yang dituntut untuk memiliki kemampuan menulis secara ilmiah tetapi siswa pun dituntut juga untuk memiliki kemampuan menulis secara ilmiah. Kemampuan menulis bukan merupakan suatu hal yang mudah untuk dilakukan 
khususnya oleh siswa. Fenomena yang ada menunjukkan bahwa ketertarikan siswa untuk mempunyai kebiasan menulis masih sangat rendah, yang mana hal ini juga terjadi pada siswa SMA Ulul Albab Sidoarjo dan SMA Dharma 4 Wanita Sidoarjo. Meski berbagai macam upaya sudah dilakukan oleh pihak sekolah maupun guru untuk mendongkrak peserta didik atau siswa memiliki kemampuan menulis diantaranya melalui pelatihan, pendampingan maupun kompetisi penulisan karya ilmiah yang dilakukan secara internal. Kendala-kendala yang dihadapi oleh siswa adalah 1) rendahnya minat siswa untuk membaca dan menulis, 2) keterbatasan kesediaan bahan bacaan yang bisa menjadi bahan tulisan, 3) tidak adanya rasa percaya diri dan kurangnya pengalaman untuk menulis, 4) rendahnya motivasi siswa untuk menulis.

Untuk mampu menumbuhkan minat dan ketrampilan menulis siswa, seorang guru pendamping dalam kegiatan penulisan karya tulis ilmiah (KTI) harus mampu memahami sistematika dan teknik penulisan karya ilmiah yang baik dan benar yang tersusun secara sistematis, logis, dan cermat termasuk dari segi bahasa. Kemampuan menulis bagi guru tidak hanya bisa ditularkan kepada siswa tapi lebih dari itu kemampuan menulis merupakan sebuah tuntutan dari profesi guru untuk mengembangkan karirnya.

Sehingga dalam hal ini, seorang guru dituntut untuk mampu menulis karya ilmiah yang berupa gagasan tertulis atau ide ide ilmiah yang lain. Karena hal ini terkait dengan kompetensi guru yang terlebih dahulu harus menguasai tata cara dalam menulis karya ilmiah. Disamping guru harus menguasai tata cara dalam menulis ilmiah, guru harus paham tentang konten yang akan dibahas oleh siswa pada saat menulis karya ilmiah siswa. Konten yang dimaksud adalah berupa konten materi, identifikasi masalah, dan metodologi penelitian yang tepat dan sesuai untuk diterapkan pada karya tulis ilmiah siswa

Berdasarkan pada analisis situasi yang dikemukakan diatas, maka dapat diidentifikasi beberapa permasalahan yaitu bagimana: 1) pelaksanaan pelatihan penulisan karya tulis ilmiah bagi guru di SMA Sidoarjo, 2) pemahaman guru terkait dengan teknik penilaian karya tulis ilmiah siswa, 3) respon guru terhadap pelatihan penulisan karya tulis ilmiah bagi guru di SMA Sidoarjo.

Kerangka pemecahan masalah dalam kegiatan PKM ini dapat digambarkan sebagai berikut:

1. Secara periodik SMA Ulul Albab dan SMA Dharma Wanita 4 Sidoarjo mengadakan kompetisi penulisan karya tulis ilmiah (KTI) bagi siswa

2. Siswa kurang memahami sistematika penulisan karya tulis ilmiah yang baik dan benar

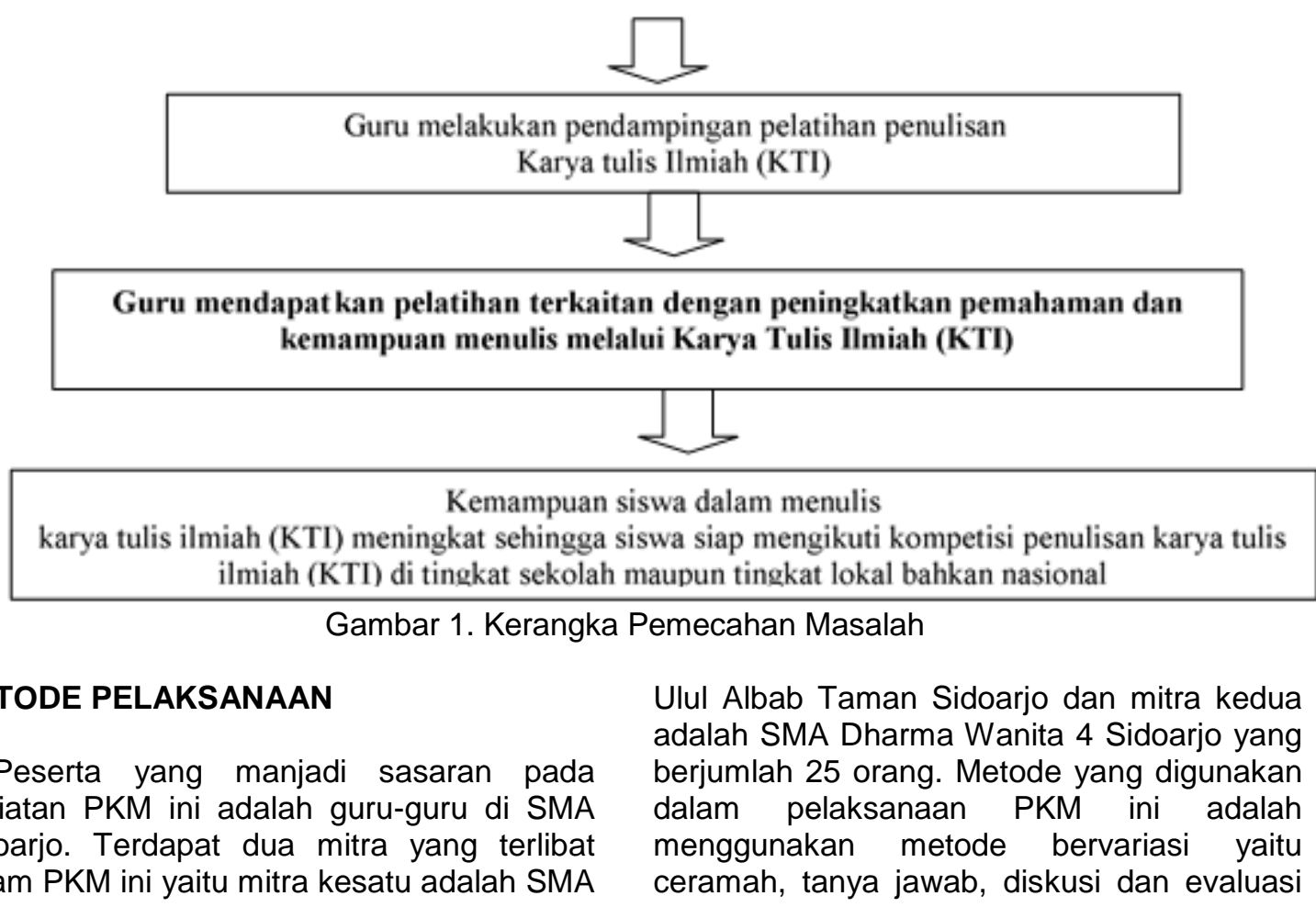


hasil penulisan karya tulis ilmiah siswa. Adapun materi yang disampaikan disusun sebagai berikut:

1. Pengertian dan karakteristik Karya Tulis Ilmiah berbasis penelitian

2. Bentuk dan tujuan penulisan karya tulis ilmiah

3. Sistematika penulisan Karya Tulis IImiah

4. Tips dan trik membuat Karya Tulis IImiah

5. Penyusunan dan penilaian Karya Tulis Ilmiah

Dalam kegiatan PKM ini dua sekolah mitra diberikan buku pedoman tentang penulisan Karya Tulis IImiah (KTI) dan seluruh peserta pelatihan diberikan hand out tentang penulisan Karya Tulis IImiah (KTI).

\section{HASIL DAN PEMBAHASAN}

Kegiatan PKM Pelatihan Penulisan Karya Tulis IImiah (KTI) ini dilaksanakan pada tanggal 30 September 2016 di SMA Ulul Albab Taman Sidoarjo yang beralamat di Jl. Bebekan Masjid No.1-2 Sepanjang Sidoarjo.

\section{Pelaksanaan Pelatihan Penulisan Karya Tulis IImiah}

Sebelum melakukan kegiatan PKM, tim terlebih dahulu melaksanakan tahapan persiapan. Pada tahap persiapan ini, sebelum pelaksanaan kegiatan PKM ini, tim melaksanakan rapat koordinasi untuk melakukan penyusunan proposal pelatihan Karya Tulis IImiah (KTI) dengan menetapkan dua mitra untuk kegiatan ini. Selanjutnya tim pelaksana melakukan observasi lapangan kepada dua mitra dengan hari yang berbeda. Setelah observasi lapangan dilakukan tim pelaksana menentukan waktu pelaksanan PKM. Selanjutnya tim melakukan penyusunan bahan materi dan kelengkapan lain terkait dengan pelaksanaan kegiatan PKM yang berupa buku pedoman dan handout.

Pada tahap pelaksanaan PKM Pelatihan Karya Tulis Ilmiah (KTI) ini dapat dideskripsikan sebagai berikut, moderator dalam pelaksanaan PKM ini adalah Renny Dwijayanti, S.Pd, M.Pd. Materi pertama yang disampaikan dalam kegiatan PKM ini adalah pengertian dan karakteristik Karya Tulis Ilmiah yang dipaparkan oleh Novi Marlena, S.Pd, M.Si Selanjutnya materi kedua tentang Bentuk dan tujuan penulisan karya tulis ilmiah dipaparkan oleh Renny Dwijayanti, S.Pd, M.Pd. Setelah selesai penyampaian materi
Bentuk dan tujuan penulisan karya tulis ilmiah dilanjutkan oleh Finisica D Patrikha, S.Pd, M.Pd dengan materi Sistematika penulisan Karya Tulis IImiah dan Tips dan trik membuat Karya Tulis IImiah. Dan materi terakhir tentang Penyusunan dan penilaian Karya Tulis IImiah disampaikan oleh Dr. Parjono, M.Si.

Setelah kegiatan penyampaian materi, tanya jawab dan diskusi selesai tim pelaksana PKM melakukan pendampingan dengan melakukan review hasil dari penilaian bimbingan KTI siswa yang sudah dipersiapkan sebelumnya oleh peserta pelatihan.

\section{Pemahaman guru terkait dengan teknik penilaian karya tulis ilmiah siswa.}

a. Pembimbingan

Proses pembimbingan dilaksanakan selama pelatihan berlangsung. yaitu dengan cara melakukan review hasil penilaian guru pada saat KTI siswa yang sudah ada yang dibawa oleh beberapa guru. Guru diminta untuk menilai karya tulis siswa berdasarkan beberapa indikator penilaian. Dari indikator penilaian yang telah diisi oleh guru, maka akan dapat terlihat apakah guru tersebut sudah mampu memahami materi yang telah disampaikan oleh narasumber (tim pelaksana PKM). Peserta pelatihan sangat antusias dalam kegiatan tanya jawab dan diskusi pada sesi penyampaiann materi pelatihan.

b. Evaluasi Pelaksanaan Pelatihan

Untuk mengevaluasi pelaksanaan kegiatan PKM ini dilakukan dengan menyebarkan angket. Guru diminta mengisi angket respon dari kegiatan pelatihan yang telah dilakukan oleh tim pelaksana PKM. Hasil dari angket respon tersebut dianalisis dan selanjutnya dideskripsikan. Tim pelaksana PKM juga melakukan reviewer dari beberapa hasil KTI yang sudah ada yaitu KTI siswa yang sudah dibimbing oleh peserta pelatihan.

\section{Respon guru terhadap pelatihan penulisan karya tulis ilmiah bagi guru di SMA Sidoarjo}

Pada tahapan ini guru diminta untuk mengisi angket tertutup mengenai respon guru terhadap pelatihan penulisan yang telah dilaksanakan oleh Tim PKM Unesa. Berdasarkan hasil respon yang di isi oleh peserta terkait dengan kegiatan PKM dapat dipresentasekan pada grafik berikut ini: 


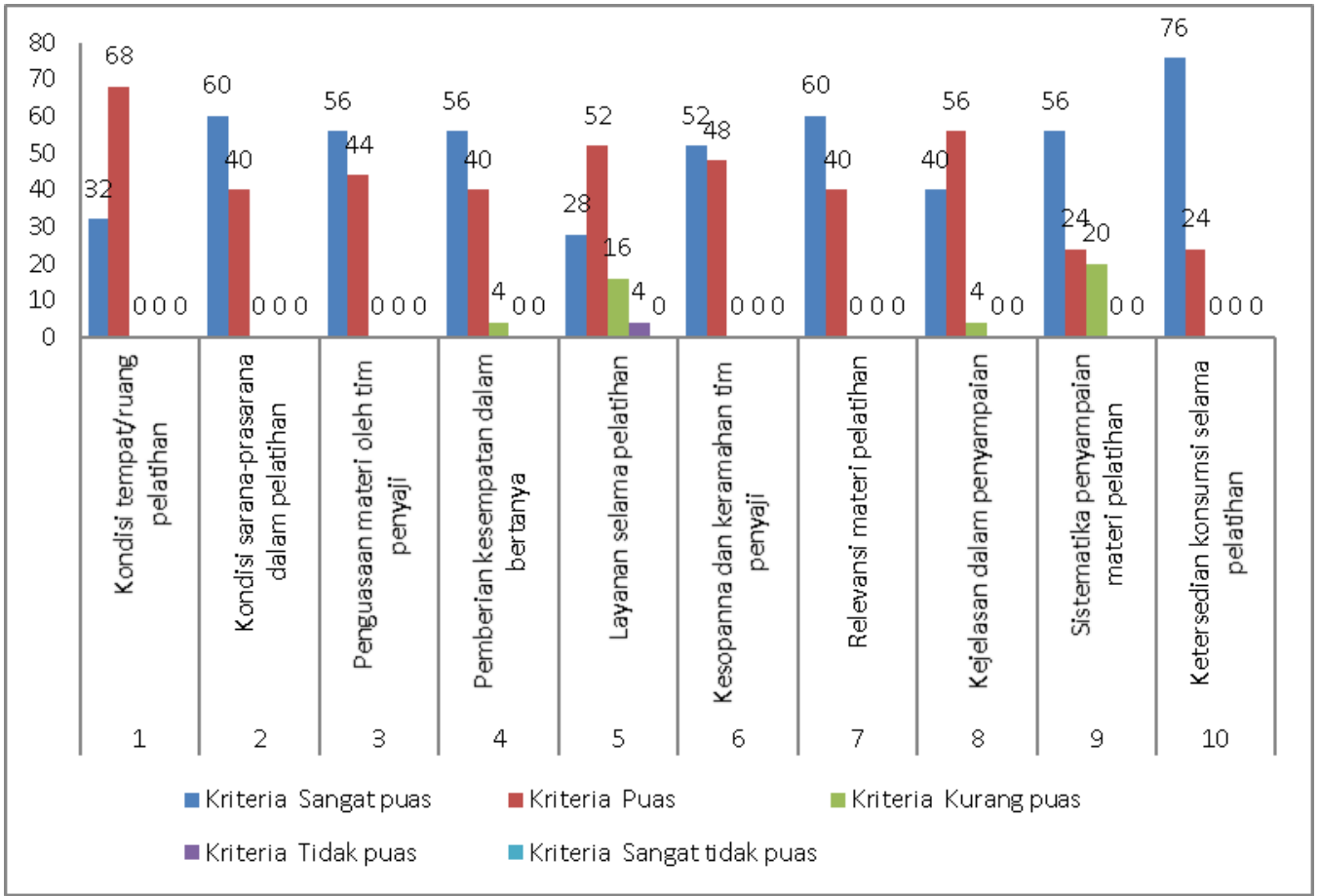

Grafik 1 Respon peserta pelatihan terkait Pelatihan Karya Tulis IImiah (KTI)

Berdasarkan hasil angket yang dibagikan pada peserta pelatihan Pelatihan Karya Tulis IImiah (KTI), maka didapatkan hasil bahwa peserta pelatihan KTI merasakan sangat puas atas kondisi sarana dan parasarana dalam pelatihan, penguasaan materi oleh tim penyaji, pemberian kesempatan dalam bertanya, kesopanan dan keramahan tim penyaji, relevansi materi pelatihan, sistematika penyampaian materi pelatihan dan ketersediaan konsumsi selama pelatihan. Sedangkan respon peserta pelatihan yang marasakan puas atas kondisi tempat atau ruang pelatihan, layanan selama pelatihan, dan kejelasan dalam penyampaian materi $\mathrm{KTI}$.

Hasil respon peserta pelatihan PKM tersebut dapat dideskripisikan untuk masingmasing angket sebagai berikut:.

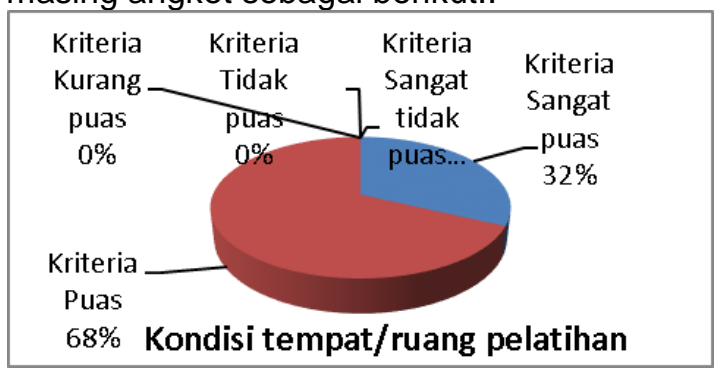

Gambar 2 Kondisi tempat/ruang pelatihan

Berdasarkan diagram di atas, respon peserta pelatihan terkait dengan kondisi tempat atau ruang pelatihan merasakan sangat puas sebanyak $68 \%$ dan merasa puas sebanyak $32 \%$.

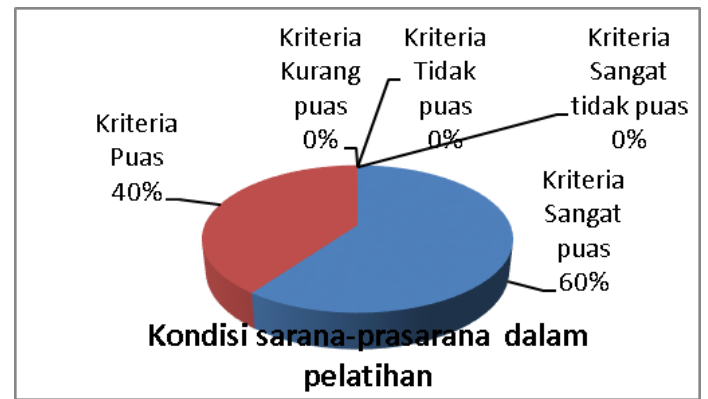

Gambar 3 Kondisi sarana dan prasarana dalam pelatihan

Berdasarkan diagram di atas, respon peserta pelatihan terkait dengan kondisi sarana dan prasarana dalam pelatihan merasakan sangat puas sebanyak $60 \%$ dan merasa puas sebanyak $40 \%$

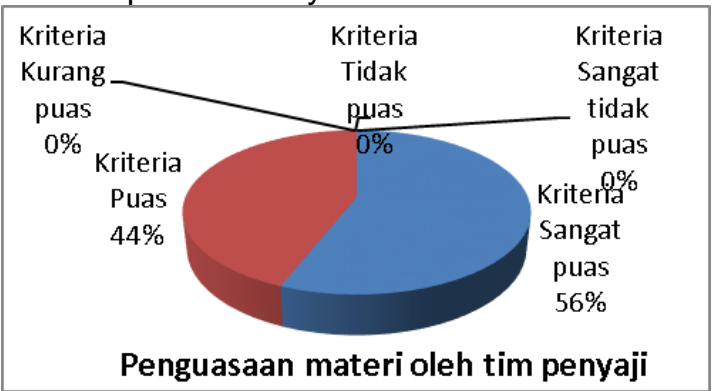

Gambar 4 Penguasaan materi oleh tim penyaji 
Berdasarkan diagram di atas, respon peserta pelatihan terkait dengan penguasaan materi tim penjayi dalam pelatihan PKM merasakan sangat puas sebanyak $56 \%$ dan merasa puas sebanyak $44 \%$.

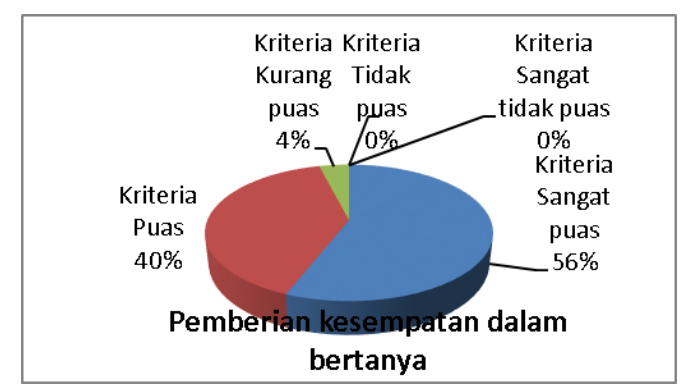

Gambar 5 Pemberian kesempatan dalam bertanya

Berdasarkan diagram di atas, respon peserta pelatihan terkait dengan pemberian kesempatan dalam bertanya dalam pelatihan PKM merasakan sangat puas sebanyak $56 \%$, merasa puas sebanyak $40 \%$ dan kurang puas sebanyak $4 \%$.

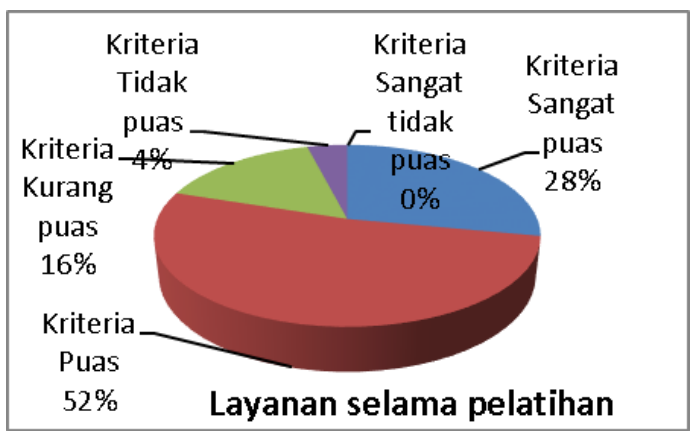

Gambar 6 Layanan selama pelatihan

Berdasarkan diagram di atas, respon peserta pelatihan terkait dengan layanan selama pelatihan dalam pelatihan PKM merasakan sangat puas sebanyak $28 \%$, merasa puas sebanyak $52 \%$, kurang puas sebanyak $16 \%$ dan tidak puas sebanyak $4 \%$.

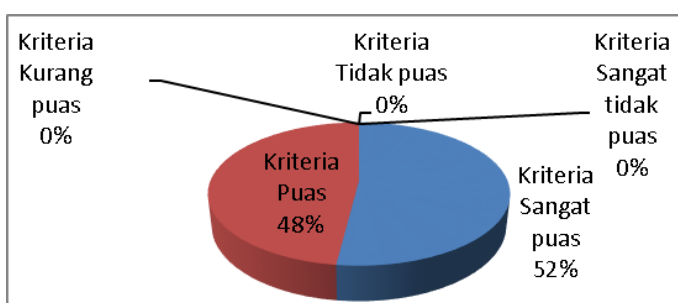

Kesopanan dan keramahan tim penyaji

Gambar 7 Layanan selama pelatihan

Berdasarkan diagram di ataas, respon peserta pelatihan terkait dengan kesopanan dan keramahan tim penyaji selama pelatihan dalam pelatihan PKM merasakan sangat puas sebanyak $52 \%$, dan merasa puas sebanyak $48 \%$.

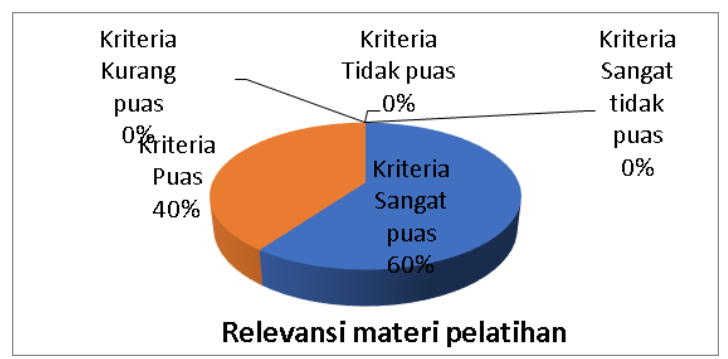

Gambar 8 Relevansi materi pelatihan

Berdasarkan diagram di atas, respon peserta pelatihan terkait dengan relevansi materi pelatihan pelatihan PKM merasakan sangat puas sebanyak $60 \%$, dan merasa puas sebanyak $40 \%$.

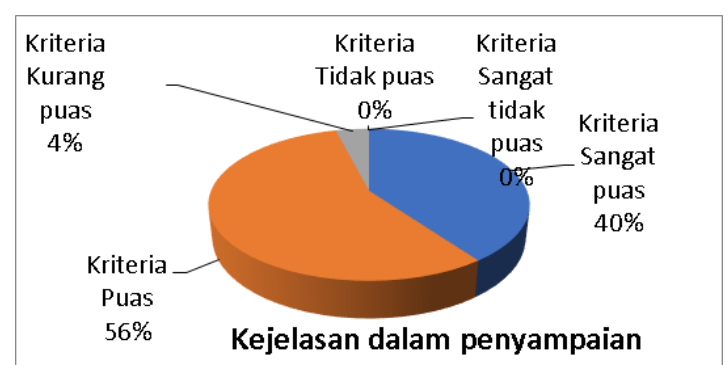

Gambar 9 Kejelasan dalam penyampaian materi pelatihan $\mathrm{KTI}$

Berdasarkan diagram di atas, respon peserta pelatihan terkait dengan kejelasan dalam penyampaian materi pelatihan $\mathrm{KTI}$ merasakan sangat puas sebanyak $40 \%$, merasa puas sebanyak $56 \%$ dan kurang puas sebanyak $4 \%$.

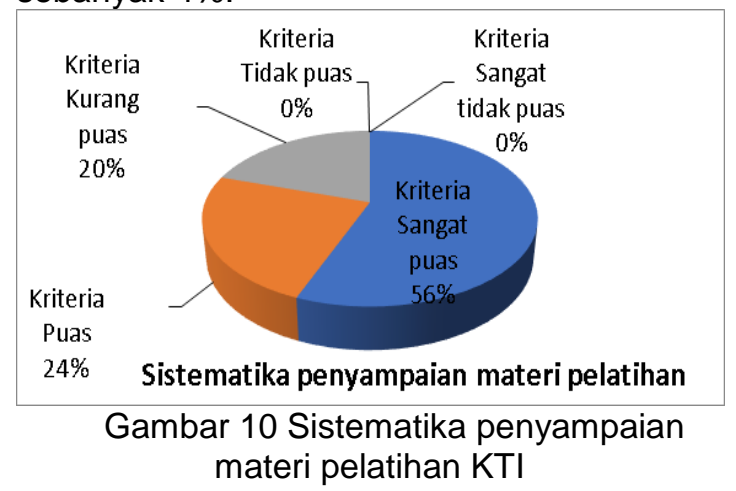

Berdasarkan diagram di atas, respon peserta pelatihan terkait dengan sistematika penyampaian materi pelatihan KTI merasakan sangat puas sebanyak $56 \%$, merasa puas sebanyak $24 \%$ dan kurang puas sebanyak $20 \%$. 


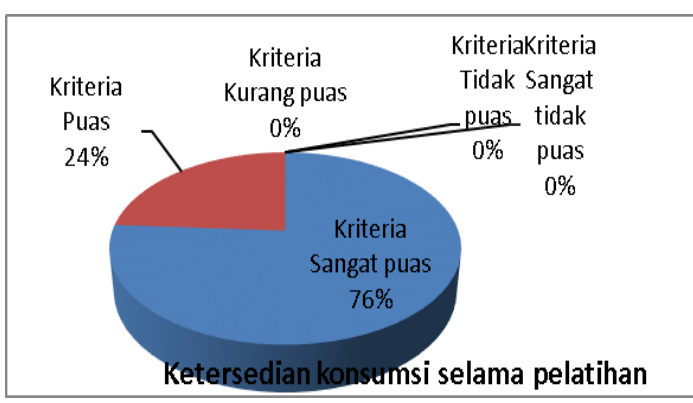

Gambar 11 Ketersediaan konsumsi selama pelatihan $\mathrm{KTI}$

Berdasarkan diagram di atas, respon peserta pelatihan terkait dengan ketersediaan konsumsi selama pelatihan $\mathrm{KTI}$ merasakan sangat puas sebanyak $76 \%$, dan merasa puas sebanyak $24 \%$

\section{SIMPULAN DAN SARAN}

Dari hasil pembahasan, dapat diambil beberapa simpulan, antara lain: 1) Pelaksanaan pelatihan penulisan karya ilmiah bagi guru SMA di Sidoarjo telah sesuai dengan tahapan yang telah direncanakan sebelumnya. Pelatihan dilakukan pada dua mitra, yaitu SMA Ulul Albab dan SMA Dharma Wanita 4 Sidoarjo, 2) Pemahaman guru terhadap teknik penilaian penulisan karya tulis ilmiah siswa diukur dengan menggunakan format penilaian karya tulis ilmiah siswa yang sudah disusun oleh sekolah, 2) Secara keseluruhan respon peserta pelatihan Karya Tulis IImiah ini merasakan sangat puas terhadap pelatihan yang diberikan terutama terkait dengan kondisi sarana dan parasarana dalam pelatihan, penguasaan materi oleh tim penyaji, pemberian kesempatan dalam bertanya, kesopanan dan keramahan tim penyaji, relevansi materi pelatihan, sistematika penyampaian materi pelatihan dan ketersediaan konsumsi selama pelatihan.

Dari hasil pembahasan, dapat diambil beberapa saran, antara lain: 1) Untuk meningkatkan pemahaman materi pelatihan Karya Tulis IImiah (KTI) perlu dilakukan pembimbingan secara insentif dan praktik penulisan secara langsung, 2) Indikator format penilaian penulisan karya tulis dapat ditambahkan indikator yang lain yaitu kebaruan topik/tema, kedalaman konten materi, penggunaan bahasa yang ilmiah, serta indikator lain yang disesuaikan dengan kebutuhan penulisan karya tulis ilmiah.

\section{DAFTAR PUSTAKA}

Dwiloka, Bambang. 2005. Teknik Menulis Karya IImiah. Bandung: Rineka Cipta

Hariwijaya. 2008. Pedoman Penulisan IImiah proposal dan Skripsi. Tugu Publisher.

Kamarosied Herry. 2009. Menulis Karya IImiah untuk Jabatan Guru (Bimbingan Praktis, Mudah dan Aplikatif. Jakarta: Gaung Persada (GP Press)

Kusmana Suherli. 2010. Merancang Karya Tulis IImiah. Bandung: PT Remaja Rosdakarya

Maryadi. 2002. Pengertian Karya Ilmiah dalam Pembudayaan Penulisan Karya IImiah. Surakarta:UMS Press

Sudjana, Nana., Ulung Laksamana. 2008. Menyusun Karya Tulis IImiah. Bandung: Sinar Baru Algensindo

Wibowo Wahyu. 2011. Cara Cerdas Menulis Aertikel Ilmiah. Jakarta: PT Kompas Media Nusantara 